\title{
Role of the Hudson Bay lowland as a source of atmospheric methane
}

\author{
Nigel T. Roulet, ${ }^{1}$ A. Jano, ${ }^{2}$ C. A. Kelly, ${ }^{3}$ L. F. Klinger, ${ }^{4}$ T. R. Moore, ${ }^{5}$ \\ R. Protz, ${ }^{6}$ J. A. Ritter, ${ }^{7}$ and W. R. Rouse ${ }^{8}$
}

Abstract. Based on point measurements of methane flux from wetlands in the boreal and subarctic regions, northern wetlands are a major source of atmospheric methane. However, meagurements have not been carried out in large continuous peatlands such as the the Hudson Bay Lowland (HBL) $\left(320,000 \mathrm{~km}^{2}\right)$ and the Western siberian lowland $\left(540,000 \mathrm{~km}^{2}\right)$, which together account for over $30 \%$ of the wetlands north of $40^{\circ} \mathrm{N}$. To determine the role the Hudson Bay Lowland as a source of atmospheric methane, fluxes were measured by enclosures throughout the 1990 snowfree period in all the major wetland types and also by an aircraft in July. Two detailed survey areas were investigated: one $\left(\approx 900 \mathrm{~km}^{2}\right)$ was in the high subarctic region of the northern lowland and the second area $\left(\approx 4,800 \mathrm{~km}^{2}\right)$ straddled the Low Subarctic and High Boreal regions of the southern lowland. The fluxes were integrated over the study period to produce annual methane emissions for each wetland type. The fluxes were then weighted by the area of 16 different habitata for the southern area and 5 habitats for the northern area, as determined from Landeat thematic mapper to yield an annual habitat-weighted emission. On per unit area basis, $1.31 \pm 0.11$ and $2.79 \pm 0.39$ $\mathrm{g} \mathrm{CH}_{4} \mathrm{~m}^{-2} \mathrm{yr}^{-1}$ were emitted from the southern and northern survey areas, respectively. The extrapolated enclosure estimates for a 3-week period in July were compared to within 108 of the flux derived by airborne eddy correlation measurements made during the same period. The aircraft mean flux of $10 \pm 9 \mathrm{mg} \mathrm{CH} \mathrm{m}^{-2} \mathrm{~d}^{-1}$ was not otatiatically different from the extrapolated mean flux of $20 \pm 16 \mathrm{mg} \mathrm{CH} \mathrm{m}^{-2} \mathrm{~d}^{-1}$. The annual habitatweighted emiagion for the entire HBL uging $\mathrm{gix}$

\footnotetext{
${ }^{1}$ Department of Geography, York University, North York, Ontario.

${ }^{2}$ Ontario Centre for Remote Sensing, North York, Ontario.

${ }^{3}$ Department of Microbiology, University of Manitoba, Winnipeg.

${ }^{4}$ National Center for Atmospheric Research, Boulder, Colorado.

'Department of Geography, McGill University, Montreal, Quebec.

'Land Resource Science, Guelph University, Guelph, Quebec.

7Atmospheric Science Division, NASA Langley Research Center, Hampton, Virginia.

${ }^{8}$ Department of Geography, McMaster University, Hamilton, Ontario.
}

Copyright 1994 by the American Geophysical Union.

Paper number 93JD000261.

0148-0227/94/93JD-00261\$05.00 wetland classes is estimated as $0.538 \pm 0.187 \mathrm{Tg}$ $\mathrm{CH}_{4} \mathrm{yr}^{-1}$ (range of extreme cases is 0.057 to 2.112 $\mathrm{Tg}^{4} \mathrm{CH}_{4} \mathrm{yr}^{-1}$ ). This value is much lower than expected, based on previous emission estimates from northern wetlands.

\section{Introduction}

The concentration of atmospheric methane $\left(\mathrm{CH}_{4}\right)$ has doubled over the last 200 years. It is currently $1720 \mathrm{ppb}(\mathrm{v})$ and is increasing at a rate of between 0.8 and $1.0 \% \mathrm{yr}^{-1}$ (Intergovernmental Panel on Climate Change (IPCC), 1990]. To maintain the current concentration and rate of increase, between 505 and $550 \mathrm{Tg} \mathrm{CH}_{4}$ [Crutzen, 1991) should be emitted annually from all sources. In the present estimater, approximately $20 \%$ of the $\mathrm{CH}_{4}$ 1e provided by each of wetlande, ruminante and termites, rice paddies, with the remaining 40 \% from human activities such as coal and natural gas extraction, the transport of natural gas and landfille [Fung et al., 1991], but these egtimates have considerable uncertainities.

Wetlands have received much attention because they are the largest natural source [Fung et al., 1991]. Estimates of the present-day source strength for wetlands vary between 80 [Aselmann and Crutzen, 1989] and $115 \mathrm{Tg} \mathrm{CH}_{4} \mathrm{yr}^{-1}$ [Matthews and Fung, 1987; Fung et al., 1991]. The firgt global estimate set the net emissions for wetlands north of $40^{\circ} \mathrm{N}$ at $70 \mathrm{Tg} \mathrm{CH} \mathrm{yr}^{-1}$ [Matthews and Fung, 1987], but later eatimates were lower, ranging from 22 [Agelmann and crutzen, 1989] to 35 $\mathrm{Tg} \mathrm{CH} \mathrm{yr}^{-1}$ [Fung et al., 1991]. These eetimates are all based on flux measurements taken outside the two most extensive wetlands in the north: the Hudeon Bay lowland $\left(320,000 \mathrm{~km}^{2}\right.$ [Cowell, 1982] and the Western Siberian lowland $\left(540,000 \mathrm{~km}^{2}\right.$ [Botch and Masing, 1983]. These two wetlands comprise over $30 \%$ of all wetlands north of $40^{\circ} \mathrm{N}$.

The purpose of this paper is to estimate the role of the Hudion Bay lowland (HBL) as a source of atmospheric methane using data from the ground and aircraft surveys undertaken during the 1990 Northern Wetlands Study (NOWES) [Roulet et al., 1992a]. A hierarchical linear model based on the areal coverage of wetland types derived from Landsat thematic mapper (TM) is used to extrapolate point flux measurements within two survey regions of $\approx 4800$ and $\approx 900 \mathrm{~km}^{2}$ each. Methane emitted from the entire HBL is estimated using surface flux meagurements from both peat and open water surfaces [Hamilton et al., this issue; Holland, 1992; Klinger et al., this issue; Moore et al., this issue] and the areal coverage of wetlands obtained from ecological studies [Riley, 1982]. The average methane flux was also obtained for several weeks in July by airborne eddy correlation measurements [Ritter et al., this 
issue]. These data will serve as a comparison for the extrapolated enclosure egtimates.

The HBL is a unique environment for the study of methane emissions because of its areal extent, its almost continuous coverage of peat, and the gequential manner in which the peatlands have developed. Isostatic emergence of the coastlines of James and Hudson Bays over the last 8000 years has resulted in a general sequence of wetlands from saltwater marshes of several hundred years of age at the coast to large complex peatland ecosystems of over 5000 years of age in the interior of the HBL [Riley, 1982]. The measurement program utilized this pattern to examine how methane emissions change along a 140- $\mathbf{k m}$ transect that represents 5000 years of peatland development and contains most of the wetland types of the high boreal and subarctic climate regions.

\section{Study Area}

The Hudson Bay Lowland

The climatology, ecology, and physical characteristics of the HBL are summarized by Mortsch [1990]. The lowland lies between $50^{\circ}$ to $58^{\circ} \mathrm{N}$ latitude and $77^{\circ}$ to $94^{\circ} \mathrm{W}$ longitude (Figure 1). Approximately 265,000 (838), 47,500 (158), and $7,000 \mathrm{~km}^{2}(2 \%)$ of the HBL are located in the provinces of Ontario, Manitoba, and quebec, respectively. The HBL encompasses four

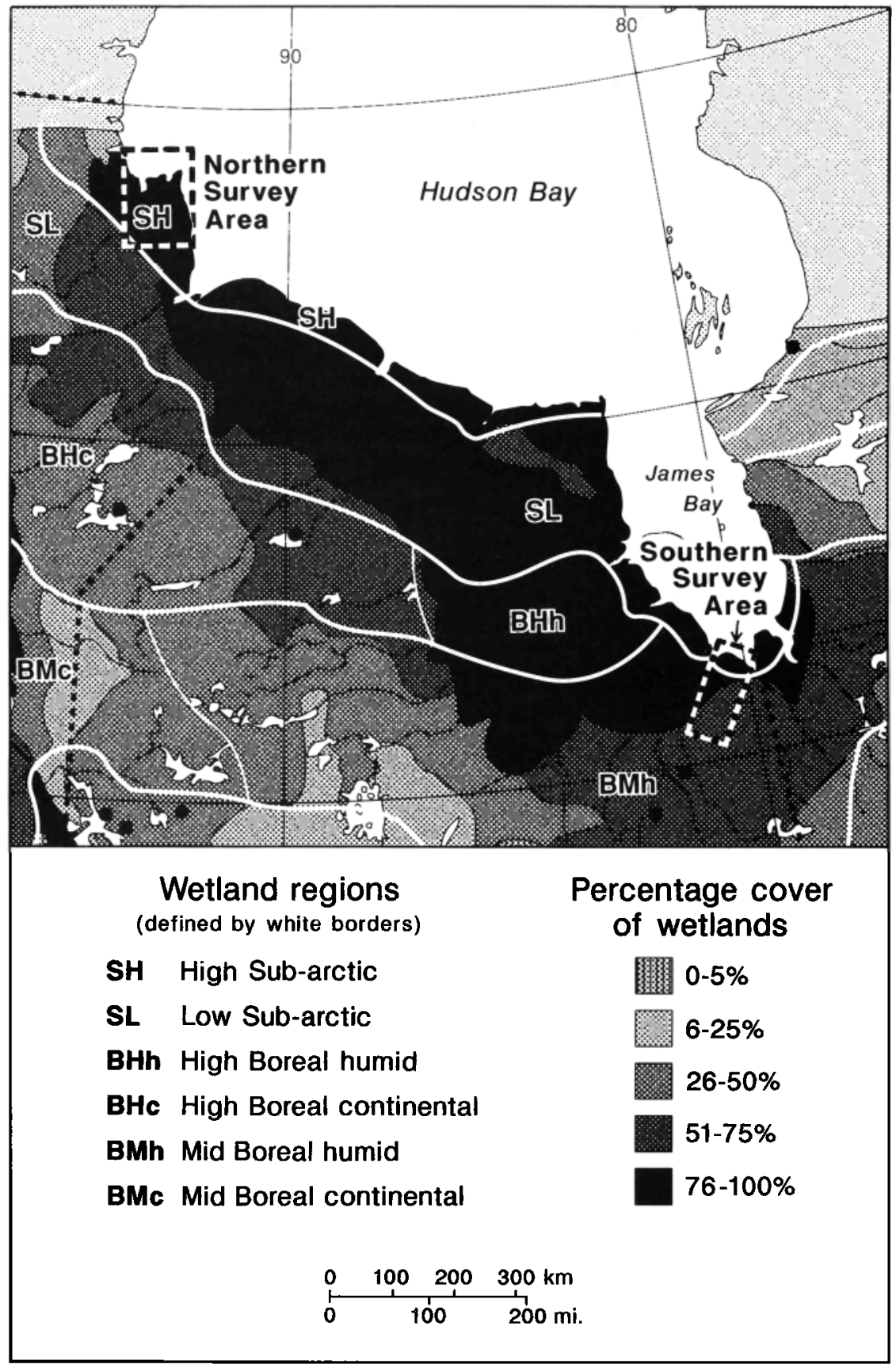

Fig. 1. The ecoclimatic regions of the Hudson Bay lowland (HBL) and the two survey areas. 
ecoclimatic wetland zones: the humid mid (BMh) and humid high boreal (BHh) and the low (LSA) and high subarctic (HSA) regions [National Wetlands Working Group (NWWG) 1988]. These regions are defined largely on the basis of January and June mean monthly air temperature and annual precipitation: $B M h$, January $-15^{\circ}$ to $-23^{\circ} \mathrm{C}$; June, $13^{\circ}$ to $18^{\circ} \mathrm{C}$ and 650 to $1000 \mathrm{~mm}$; BHh, January $-23^{\circ}$ to $-25^{\circ} \mathrm{C}$; June $12^{\circ}$ to $14^{\circ} \mathrm{C}$, and 600 to $800 \mathrm{~mm}$; LSA, January, $-23^{\circ}$ to $-30^{\circ} \mathrm{C}$; June $14^{\circ}-17^{\circ} \mathrm{C}$ and, 300 to $500 \mathrm{~mm}$; and HSA, January, $-26^{\circ}$ to $-30^{\circ} \mathrm{C}$; June, $10^{\circ}$ to $16^{\circ} \mathrm{C}$, and 250 to $350 \mathrm{~mm}$. Over 708 of the HBL is in the low subarctic zone. The HBL extends from the zone of continuous permafrost along the Hudson Bay coast through the widespread discontinuous permafrost zone to the region where permafrost it absent [Mortsch, 1990].

Over $80 \%$ of the lowland is covered by 1 to $3 \mathrm{~m}$ deep organic fibrisols and mesisols (peats), which overlie glaciomarine silts and clays laid down during the marine inundation of the post glacial Tryell sea [Martini, 1989]. The maximum elevation of Lowland is less than $150 \mathrm{~m}$ above the mean average sea level (m.a.s.l.) and the topographic gradient from the southern perimeter to the coast is between 0.5 and $1.0 \mathrm{~m} \mathrm{~km}^{-1}$ (< 0.18 ).

Mean annual temperatures for Moosonee and Churchill at the southern and northern extremes of the HBL are $-1.2^{\circ}$ and $-7.2^{\circ} \mathrm{C}$, while the mean July temperatures are $15^{\circ}$ and $12.5^{\circ} \mathrm{C}$ [Mortsch, 1990]. Approximately $800 \mathrm{~mm}$ of precipitation falls annually in the south and $400 \mathrm{~mm}$ in the north: 508 of this is snow. Maximum monthly precipitation occurs between June and october $1 \approx$ 50 to $80 \mathrm{~mm}^{\mathrm{month}}{ }^{-1}$ ). The 1990 snow-free period climate for the southern portion of the HBL was not atypical [Mortsch, 1991]. The departure in the 1990 mean monthly temperatures from the 1932 to 1989 mean ranged from a minimum of $-1.8^{\circ} \mathrm{C}$ in september to a maximum of $1.6^{\circ} \mathrm{C}$ in July. The pattern of precipitation was abnormal: in June, precipitation was 2008 of the long-term mean, while in July it was 728 of normal. With the exception of June however, all monthly precipitation totals were within one standard deviation of the 1932-1989 mean. In the northern portion of the HBL the snow-free period in 1990 was relatively normal with average temperatures $0.6^{\circ} \mathrm{C}$ higher and precipitation 48 greater than the 30-year means.

The distribution and ecology of the wetlands in the Ontario portion of the Lowland has been documented by Riley $[1982,1988]$. The wetlands of the Manitoba and Quebec portions of the lowland have received little attention. North of $52^{\circ} \mathrm{N}$, bogs and poor swamps dominate except in the high oubarctic zone along the coast where the marshes, thicket swamps, and fens are more common [Mortsch, 1990]. In the southern portion of the HBL, marshes dominate the coast but are replaced by fens and then bogs farther inland. Many of the inland peatlands, $\approx 20$ to $30 \mathrm{~km}$ from the coast, are covered with numerous gmall pools which in some cases occupy as much as 308 of the peatland surface.

Based on Riley's [1982] work, the coverage of the major wetland types for the ontario portion of the HBL is egtimated in Table 1 . In all regions, open or treed bogs dominate, with fens being the second most common wetland type. Throughout the HBL, uplands form between 11 and 23\% of the cover. The uplands have no cover of peat.

\section{Survey Areas}

Two areas of the HBL were selected for detailed surveys of the $\mathrm{CH}_{4}$ flux using enclosures and for ecological characterization using remote senging. The main survey area was located approximately $75 \mathrm{~km}$ north of Moosonee, Ontario, in the southern end of the James Bay basin (Figure 1). Six locations were surveyed along a transect that extended $100 \mathrm{~km}$ inland from the west coast of James Bay $\left(51^{\circ} 30^{\prime} \mathrm{N}, 80^{\circ} 28^{\prime} \mathrm{W}\right)$ to Kinosheo Lake $\left(51^{\circ} 35^{\prime} \mathrm{N}, 81^{\circ} 4 \mathrm{~B}^{\prime} \mathrm{W}\right.$ ) [see Glooschenko et al., this issue, Figure 2]. This transect will be referred to as the NP-KL transect. The NP-KL transect beging in the low subarctic zone and terminates in the mid boreal zone. At each location up to six sites, representing most of wetland types of the subarctic and boreal regions, were sampled (Table 2 ). Site selection was based on the wetland types described by Riley [1982] and the classification of each site was verified by botanical surveys conducted by J. Riley (personal communication, 1990) during the 1990 experiment.

All measurements in the northern survey area were carried out in the vicinity of churchill, Manitoba $\left(58^{\circ} 45^{\prime} \mathrm{N}, 94^{\circ} 09^{\prime} \mathrm{W}\right)$ which is located on the southwestern shore of Hudson Bay. The region is underlain by continuous permafrost and has little local relief. Wetlands comprise fens, bogs, marshes, and shallow ponds and lakes which are from 0.25 to $2 \mathrm{~m}$ deep. The vegetation in the study area is a combination of both tundra and boreal species. A more detailed description of the wetlands of this region is found in Holland [1992].

TABLE 1. Percent cover of different wetlands of the Ecoclimatic Regions of the Ontario Portion of the Hudson Bay Lowland Derived from Riley [1982] and the National Wetland Working Group [1988]

\begin{tabular}{lcccc}
\hline Wetland Region & Midboreal & High Boreal & Low Subarctic & High Subarctic \\
\hline Area, $\mathrm{km}^{2}$ & 70,640 & 41,070 & 137,448 & 16,026 \\
Marshes & 4 & 4 & 3 & 8 \\
Open fens & 3 & 9 & 19 & 26 \\
Treed fens and & 31 & 25 & 10 & 5 \\
$\quad$ swamps & 16 & 28 & 26 & 17 \\
Open bogs & 23 & 22 & 25 & 26 \\
Treed bogs & 23 & 11 & 18 & 20 \\
Dry uplands & & &
\end{tabular}


TABLE 2: Classification of the Wetlands Sampled for $\mathrm{CH}_{4}$ flux in the Southern Survey by Riley [1982; 1988], the Ontario Centre for Remote Sensing (OCRS) (See Text), and the corresponding Wetland Classified by the Canadian Wetland Classification System [NWWG, 1988]

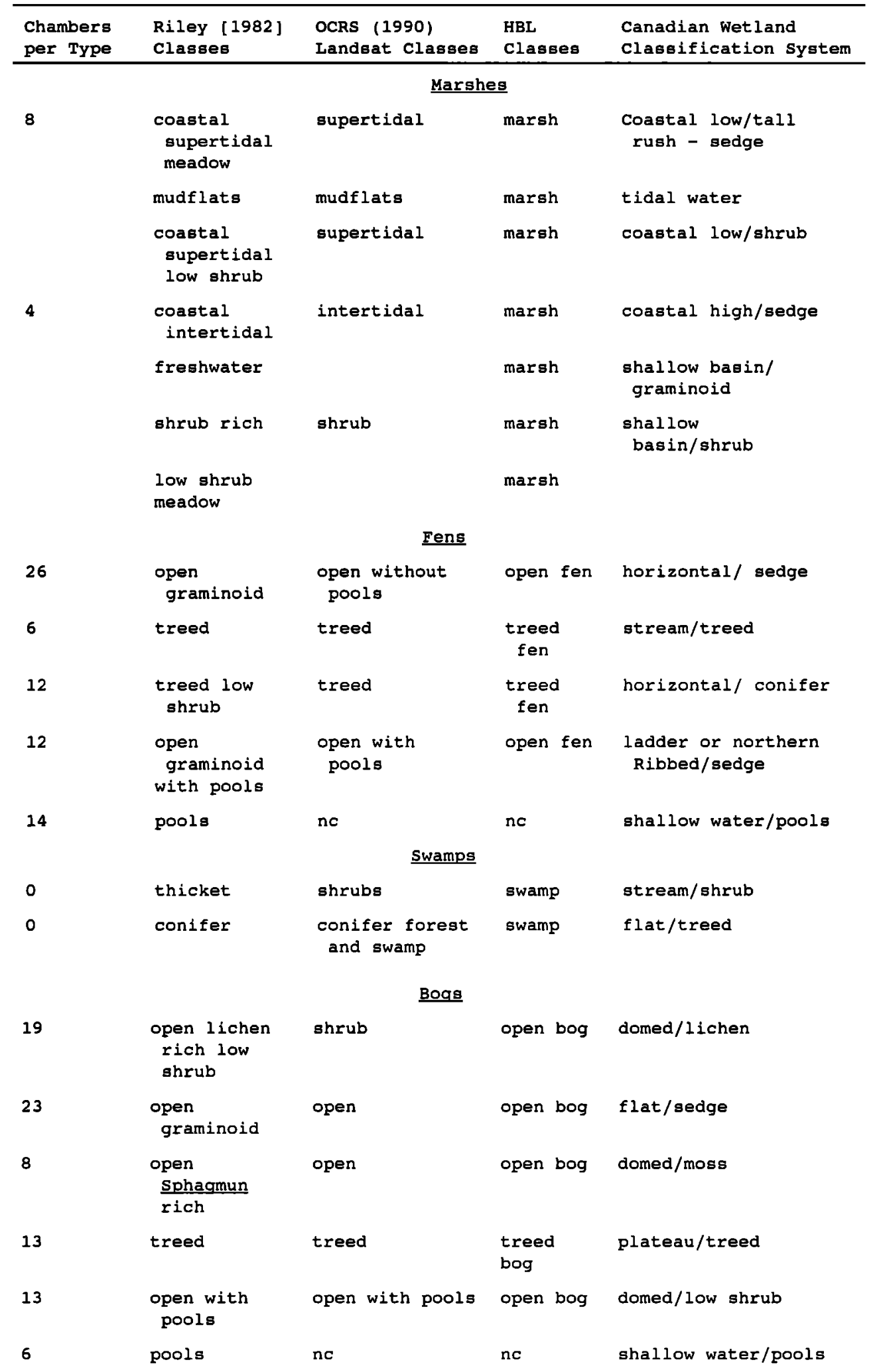


TABLE 2 (continued)

\begin{tabular}{|c|c|c|c|c|}
\hline $\begin{array}{l}\text { Chambere } \\
\text { per Type }\end{array}$ & $\begin{array}{l}\text { Riley [ 1982] } \\
\text { Clagses }\end{array}$ & $\begin{array}{l}\text { OCRS (1990) } \\
\text { Landsat Classes }\end{array}$ & $\begin{array}{l}\text { HBL } \\
\text { Classes }\end{array}$ & $\begin{array}{l}\text { Canadian Wetland } \\
\text { Clageification syotem }\end{array}$ \\
\hline \multicolumn{5}{|c|}{ Lakeg } \\
\hline 6 & Nc & Water & nc & nc \\
\hline \multicolumn{5}{|c|}{ Uplands } \\
\hline 4 & Aspen & ne & upland & ne \\
\hline 8 & $\begin{array}{r}\text { Conifer } \\
\text { upland }\end{array}$ & $\begin{array}{l}\text { Conifer forest } \\
\text { and swamp }\end{array}$ & upland & ne \\
\hline
\end{tabular}

Here, nc aignifies not classified.

Methods

To estimate the total amount of methane emitted from the HBL, flux measurements were made from all the major wetlands in the northern and gouthern survey areas. For the two survey areas these measurements are weighted using the fractional coverage of each wetland type obtained by remote sensing. For the flux estimate from the entire lowland, a combination of coverage estimates from remote sensing and ecological surveys was used.

\section{Determination of the Methane Flux}

Detailed descriptions of the methods used to obtain the methane flux data from the southern and northern peatlands are given by Hamilton et al. [this issue], Klinger et al. [this issue], Moore et al. [thig issue] and Holland [1992]. Over 80\% of the flux measurements were obtained using a rigid polycarbonate atatic chamber (volume $=18 \mathrm{~L}$; area $=0.053 \mathrm{~m}^{2}$ [Moore et al., this isgue; Holland, 1992 J). Fewer peatland fluxea were obtained uging flexible FEP Teflon bage supported by aluminum frames (area $=0.44 \mathrm{~m}^{2}$ ) [Klinger et al., this issue]. The pond fluxes were calculated from surface water $\mathrm{CH}_{4}$ concentrations and a continuous record of wind speed (Hamilton et al., this isoue) using the stagnant film boundary layer model and gas transfer coefficients determined by the method described by Wanninkhof et al. [1990]. The duration of chamber flux measurements varied from 30 minutes to 2 hours, while up to five samples of water were taken over a 24 hour period for the calculation of the pond flux. Each type wetland contained at least two chambers but usually five chambers. The distribution of the chambers among 16 different wetland site types is outlined in Table 2. Six sample sites were used in the northern survey. For the pond fluxes, between 5 and 15 ponds were sampled at each location on the NP-KL transect. These data were averaged to produce one flux for a location. The flux from ponds in the northern survey area was obtained using chambers. A large proportion of the methane samples were analyzed on two Shimadzu Mini-2 gas chromatographs equipped with flame ionizer detectors [Hamilton et al., this issue; Moore et al., this isaue]. A small number of the southern samples were analyzed on a baseline 103A gas chromatograph [Klinger et al., this issue]. The samples from the northern survey were shipped to
Montreal in vaccutainerg and analyzed on a Perkin Elmer 3920 FID gas chromatograph. Gas chromatograph calibrations and data quality control are discussed [Klinger et al., this issue; Moore et al., this issue]. The minimum flux detectable by the combination of the polycarbonate chambers, the shimadzu Mini-2, and a 2 hour flux run is $0.1 \mathrm{mg} \mathrm{CH} \mathrm{m}^{-2} \mathrm{~d}^{-1}$. The mimimum for the tefion chamber and the Baseline 103A and the Churchill fluxes was $1.0 \mathrm{mg} \mathrm{CH} \mathrm{m}^{-2} \mathrm{~d}^{-1}$. The lowest detectable flux from the ponds is a function of wind epeed and $\mathrm{CH}_{4}$ concentrations and is therefore variable, but at the average wind speed it is 0.1 $\mathrm{mg} \mathrm{CH}_{4} \mathrm{~m}^{-2} \mathrm{~d}^{-1}$.

In total over 1800 flux measurements were obtained in the southern survey area between June and october and 976 fluxes from the northern survey between June and september. The respective sampling periods for both ourveys represent a period when the peatlande were anow free.

The vertical flux of $\mathrm{CH}_{4}$ was also obtained via an airborne eddy correlation technique during July [Ritter et al., this issue]. Fast response $\left(\approx 20 \mathrm{~B}^{-1}\right.$ ) measuremente of $\mathrm{CH}_{4}$ and the ambient vertical velocity were made. The turbulent air motion measurement system (TAMMS) was used on the NASA Electra aircraft for measuring the lateral, longitudinal, and vertical turbulent air velocity components needed for eddy correlation flux measurementa [Ritter et al., 1993]. The gensors uged for making flow angle measurementa (rotating balsa vanes) as well as those for pressure, air temperature, and faet response water vapor measurements (Lyman alpha hygrometer) were located near the tip of a $3.7-m$ boom on the nose of the Electra. Fast response $\mathrm{CO}$ and $\mathrm{CH}_{4}$ measurements were provided by a tunable diode laser (TDL). The laser beams of two TDLs (one lasing in the 4.7- $\mathrm{m}$ $\mathrm{CO}$ band and a second in the 7.6- $\mathrm{m} \mathrm{CH}_{4}$ band) are combined and are then directed along a $10 \mathrm{~m}$ folded optical path enclosed in a 1.5-L white cell. Further details on the specifications of this ingtrument can be found in the work of sachee et al. [1991].

Determination of the Areal Coverage of Wetlands in Survey Areas

The areal extent of each wetland type was needed to extrapolate the methane fluxes. Two approaches were taken to the classification of the wetlands of the HBL. In the two survey areas, wetlands were classified by the Ontario centre for 
Remote Sensing using Landsat-TM. For the extrapolation of the fluxes to the entire HBL, the use of Landsat-TM was cost prohibitive. Fortunately, the surveys conducted by Riley [1982] were auficiently extensive that they gave detailed coverage but at a coarger resolution. Riley sampled 335 different areas in the ontario portion of the HBL yielding a sample area of $\approx 750$ $\mathrm{km}^{2}$. The effect of the aggregation of wetlands into broader classes on the regional estimate of methane emissions is examined in the results section.

Landeat-TM digital satellite image data recorded on August 6, 1990, was used for the analysis. A Landsat full frame, a rectangular array of 5700 image lines, each containing some 6300 pixels, covers an area of approximately 185 $\times 171 \mathrm{~km}\left(>31,000 \mathrm{~km}^{2}\right)$. For each $30 \times 30 \mathrm{~m}$ pixel, reflectance for seven discrete wavelengths in the visible and near infrared portion of the electromagnetic spectrum is recorded. A portion of the full Landsat scene, covering the NP-KI transect $\left(40 \times 120 \mathrm{~km}: 4800 \mathrm{~km}^{2}\right)$ was registered to the 1:50,000 NTS map sheet. This produced a new set of digital files encoded with universal transverse mercator (UTM) coordinates, measuring 1600 lines of 4700 pixels, each pixel having a Bize of $30 \times 30 \mathrm{~m}$.

From these data an infrared, red, and green band were used to produce a falle color infrared image used for vegetation classification. On the basis of field observations and past experience [eg. Pala and Boissonneau, 1982] in interpreting false color composite satellite images, representative (training) areas of significant land cover classes were selected within the transect. Field verification was done by botanical surveys conducted during the NOWES ( $\mathrm{J}$. Riley, personal communication, 1990). Twenty-one classes were selected. Statistical description of the apectral properties of the representative areas (i.e., spectral signatures) were used by a maximum likelihood classifier to create a classified image by assigning each pixel one of 26 cover classes.

The information contained in the Landsat data was modified to distinguish between spectrally similar classes on the basis of shape, distribution, contextual information, association and location within the landscape. This process yielded 26 classes, and these were merged by similar aspects relevant to the exchange of trace gases, such as vegetation type and surface wetness, to yield a final 16 classes used in the extrapolations. Three sets of cover statistics were produced: (1) the fractional component of each of the 16 wetland types for the NP-KL transect; (2) the fractional component of each wetland for 24 bands ( $5 \mathrm{~km}$ deep and $40 \mathrm{~km}$ wide) running parallel to the coast of James Bay from the coast inland to Kinosheo Lake; and (3) the fractional component of each wetland type for eight sub-transects consisting of $1925 \times 5 \mathrm{~km}$ squares.

Landsat-TM has a pixel size of $30 \times 30 \mathrm{~m}$. While this resolution is sufficient to identify the abundance of the major wetland ecosystems, including boge and fens that have a large enough portion of their surface covered with water to affect the spectral signature, it is insufficient to determine the actual percent coverage by surface water when the pools are smaller than $\approx 900$ $\mathrm{m}^{2}$. In 1989 and 1990, color air photography was flown in July for the sample locations in the southern survey area. Flight lines followed the transect at a nominal altitude of $3000 \mathrm{~m}$. A 152$\mathrm{mm}$ lens was used on a Wild RC 10 mapping camera, giving a scale of $1: 20,000$. From this air photography, pools down to a radius of $2 \mathrm{~m}$, or an area of approximately $15 \mathrm{~m}^{2}$, could be resolved. The percentage of the surface of the wetland which contained pools was determined for the 8 ix locations along the NP-KL transect. When a Landsat pixel was identified as being in the classes of open bogs with pools, or open fens with pools, the percent of pool coverage analyzed using the air photography was applied to that pixel.

A Landsat-TM scene, recorded on August 2, 1984 was used to analyze a $900 \mathrm{~km}^{2}$ area centered on Cape Churchill in the northern portion of the HBL. The image used was taken prior to the flux measurements, but the rate of landscape change in northern peatlands and the permaforet region are extremely blow [e.g. Mortsch, 1990] so that the errors attributed to the flux measurements themselves are probably much larger than those introduced by the 6-year difference. A thematic map and cover statistics of the 16 main cover types was produced using the same methods described above, but the analyeis was based on ground truthing in the Ontario portion of the HBL and not in the churchill area. Therefore the same level of accuracy as the southern transect cannot be guaranteed for the northern portion of the HBL.

\section{Extrapolation of the Fluxes}

A simple linear model was used to extrapolate the fluxes from their point of measurement to the regional scale. For the detailed survey areas the annual methane emission for a given wetland type is obtained by integrating the mean daily flux through time. The annual habitat-weighted methane emigsion is obtained by multiplying the annual methane emiasion for each wetland type by the area of that wetland type. The standard error of the extrapolated flux was calculated using a linear combination of errors [Barford, 1985] that were weighted by the square of the fractional area of the particular wetland type. The standard error is used in the analysis of errors where possible in thig paper, because it provides a better estimate of accuracy of the mean than does the standard deviation [Barford, 1985].

For the detailed survey areas, up to 12 classes of the wetlands and landscape units are uged in extrapolations. Five wetland clagses and one upland class are used to determine the annual habitat-weighted methane emission for the entire HBL.

Results

\section{Wetland Coverage}

sixteen wetland/land cover types were identified along the NP-KL transect using the Landsat-TM (Table 3; Plate 1). Treed, shrub-rich 
TABLE 3. Sixteen land cover classes Obtained by Landsat Thematic Mapper by the Ontario Centre for Remote Sensing

\begin{tabular}{lcc}
\hline \multicolumn{1}{c}{ Land Cover Type } & $\begin{array}{c}\text { Percent } \\
\text { Cover }\end{array}$ & $\begin{array}{c}\text { Flux } \\
\text { Measurements }\end{array}$ \\
\hline Water & 8.62 & yes \\
Marl lakes & 0.01 & no \\
Mudflats & 1.38 & no \\
Intertidal marshes & 0.54 & yes \\
Supertidal marshes & 0.79 & no \\
Shrubs & 3.99 & yes \\
Open fen & 10.74 & yes \\
Open fen with pools & 7.34 & yes \\
Shrub-rich treed fen & 18.51 & yes \\
Treed fen/spruce & 12.40 & yes \\
Open Bog with pools & 4.97 & yes \\
Open Shrub-rich bog & 3.57 & yes \\
Open lichen-rich bog & 4.86 & yes \\
Treed bog and swamp & 14.66 & yes \\
Conifer forest/swamp & 5.91 & yes \\
Recent burn & 0.63 & 1.08 \\
Unclassified & & no \\
\hline
\end{tabular}

fens, and open fens (with and without pools) dominate the transect, particularly over the first $50 \mathrm{~km}$ (Figures $2 \mathrm{a}$ and $2 \mathrm{~b}$ ). Open bogs and treed bogs appear approximately $20 \mathrm{~km}$ inland and cover an area equal to that of the fens by $50 \mathrm{~km}$ inland (Figures $2 a$ and $2 b$ ). The fractional components of wetland types along the transect are slightly biased toward fens when compared to the ecological surveys of Riley [1982], because a portion of the transect $(\approx 208$ of the first $30 \mathrm{~km})$ incorporates a rich, treed fen that ourrounds the Moose River valley. While these fens are a significant wetland type in the vicinity of large rivers, they are relatively ingignificant in the HBL.

In the first $20 \mathrm{~km}$ of the transect a small fraction of the open fens and very few open bogs are identified as having surficial pools (Figures $2 \mathrm{a}$ and $2 \mathrm{~b})$. However, beyond $40 \mathrm{~km}$ inland, over $40 \%$ of the open fens and 30\% of the open bogs are inundated. From the analysis of the color air photographs the surface area of fens occupied by pools changed from less than 58 at $10 \mathrm{~km}$ inland to near $40 \%$ at $30 \mathrm{~km}$ inland. Inland of this point, the mean area of standing water at the time of color photography for open feng and bogs way 31 and 418 , respectively, with the exception of two large patterned fens where the inundation was in excess of $80 \%$.

The wetland composition of the northern survey area is given in Table 4 . The most notable difference between the northern and the southern surveys is a greater area of nonwetland-type landscape in the north: $\approx 408$. The dominant wetland type was open fen. The coverage of forested wetland in the north is very low compared to the south.
Methane Flux from Survey Wetlands

In Table 5 the characteristics of the annual mean daily methane flux from the wetlands of the southern survey area are summarized. The mean methane emisgions are much lower than those observed for isolated wetlands in other northern regions [cf. Crill et al., 1988; Moore et al., 1990; Sebacher et al., 1986; Whalen and Reeburgh, 1988], especially the very low flux from fens. For all wetlands the mean flux was between 2 and 30 times larger than the median flux, indicating the frequency distribution of fluxes was skewed to smaller fluxes (Figure 3 ). For five of the wetland types the mean flux was greater than the 758 quartile. The variance observed in this survey is similar to that obtained in other regional surveys (Bartlett et al. 1989; Moore et al., 1990].

The statigtical summary presented in Table 5 is for the sampling season that extended from June to october. There was no sampling in the winter when the peatlands were frozen. Dise [1992] has shown that winter methane fluxes can comprise between 8 and 218 of the total annual flux for peatlands on the southern fringe of the boreal forest zone. However, winter temperatures in the southern HBL (January mean monthly temperature (JMMT) $=-20.4^{\circ} \mathrm{C}$ [Mortsch, 1990]) is more similar to that of central Alaska (JMMT = $22.9^{\circ} \mathrm{C}$ [Ruffner and Bair, 1985]) where whalen and Reeburgh [1988] observed little winter flux of $\mathrm{CH}_{4}$, than that of northern Minnesota (JMMT $=-12.9^{\circ} \mathrm{C}$; [Ruffner and Bair, 1985]) where Dise [1992] worked. Because frost penetrates well into the 

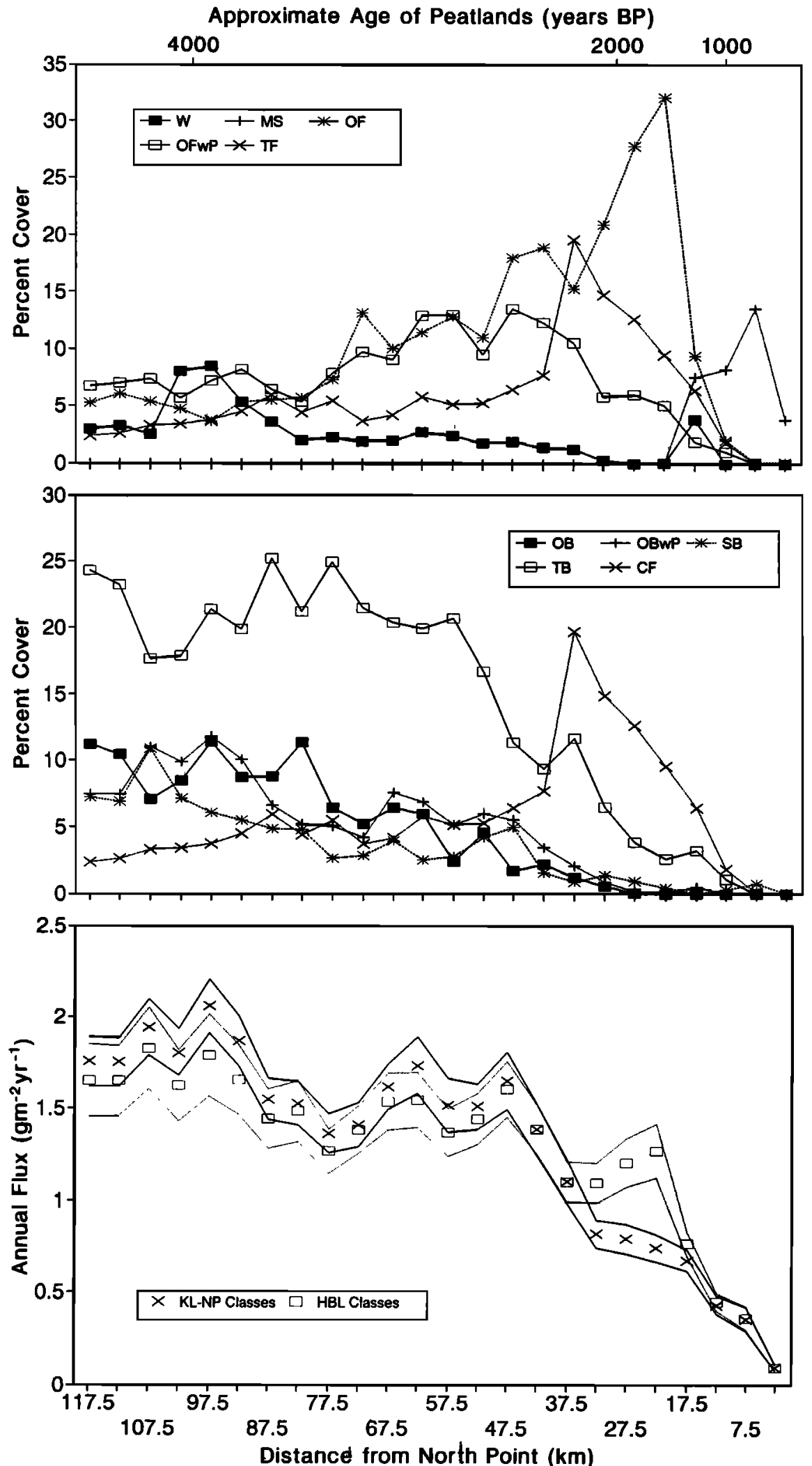

Fig. 2. (a) Percent coverage of the fens and marsheg along the NP-KL transect. $W$, water; MS, marsh; OF, open fen; OFwP, open fen with pools; and TF, tamarack. (b) Percent coverage of the bogs and forests along the NP-KL transect. OB, open bog; OBWP, Open bog with pools; SB, shrub rich bog; TB, treed bog; and CF, conifer forest/uplands. (C) Annual habitat-weighted methane emissions along the NP-KL transect. The solid curve indicates the standard error of the estimated flux using the KL-NP classes, while the soild line indicates the errors using the HBL classes. 


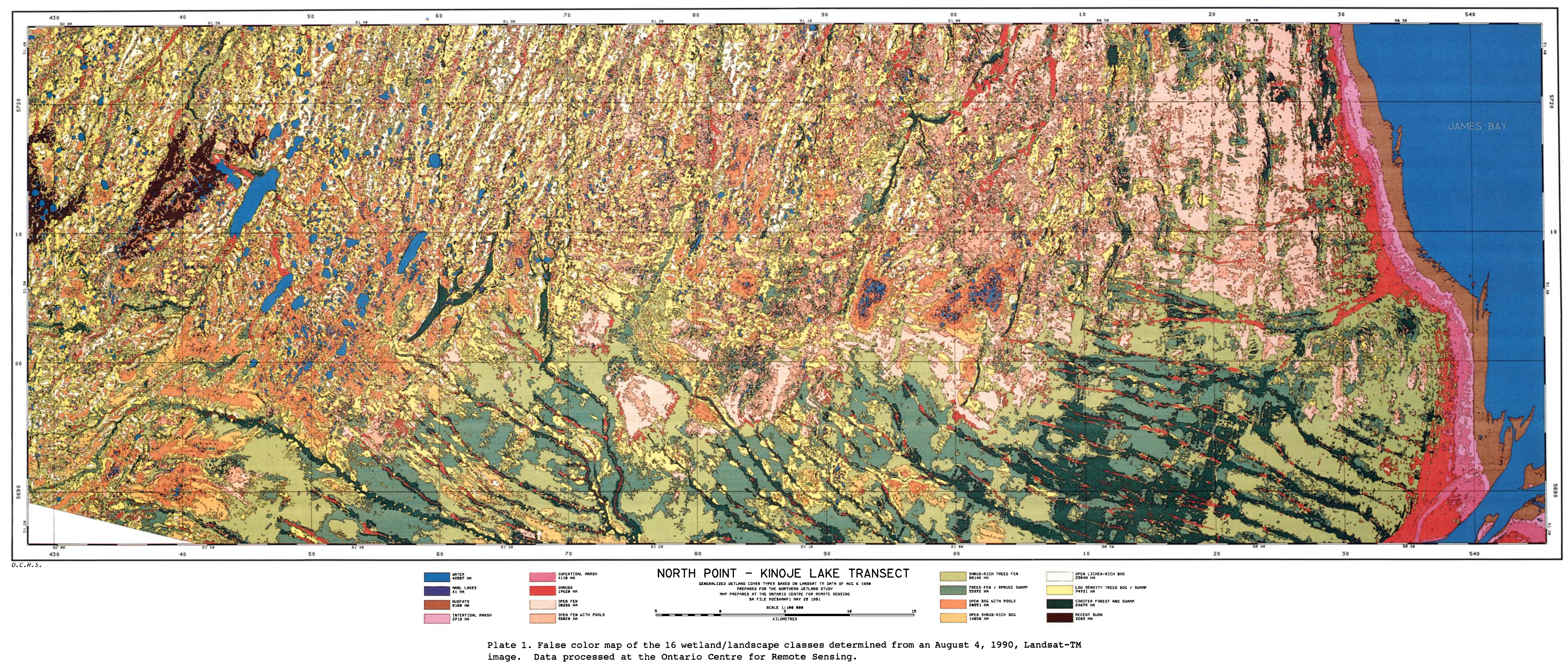


TABLE 4. Areal Extent of Wetlands in the Northern survey Area on Cape Churchill As determined by Landsat-TM for a $774.3 \mathrm{~km}^{2}$ Area

\begin{tabular}{|c|c|c|}
\hline Landcover Type & Percent Cover & Flux Measurements \\
\hline Coastal marshes & 1.2 & Yes \\
\hline Shallow lakes & 5.9 & Yes \\
\hline Open fen & 48.4 & Yes \\
\hline Treed bog & 4.1 & Yes \\
\hline Forest/woodland & 15.4 & No \\
\hline Rock outcrop & 2.5 & No \\
\hline Upland & 22.5 & No \\
\hline
\end{tabular}

TABLE 5. Annual Mean Daily Methane Flux From Wetlands on Southern Transect.

\begin{tabular}{|c|c|c|c|c|c|c|c|c|c|}
\hline Land Cover & Mean & $\begin{array}{c}\text { Standard } \\
\text { Error }\end{array}$ & Max. & Min. & Median & $\mathbf{Q} 1$ & $\mathbf{Q 3}$ & $\mathbf{N}$ & $\mathbf{F}_{\text {PT }}$ \\
\hline Water & 12.3 & 2.7 & 146.0 & 0.2 & 3.4 & 0.5 & 9.8 & 87 & 1.54 \\
\hline Marshes & 30.9 & 6.1 & 274.5 & -2.3 & 6.2 & 0.4 & 43.0 & 84 & 2.29 \\
\hline $\begin{array}{l}\text { shrubs, shrub - } \\
\text { rich treed, and } \\
\text { treed fen }\end{array}$ & 2.5 & 0.5 & 32.0 & -2.4 & 0.6 & -0.1 & 3.7 & 102 & 0.37 \\
\hline Open fen & 7.9 & 0.9 & 297.5 & -1.6 & 2.9 & 0.2 & 10.1 & 451 & 0.66 \\
\hline Fen pools & 163.0 & - & 771.0 & 15.5 & 112.0 & 65.0 & 172.0 & 62 & 13.82 \\
\hline Open bog & 53.5 & 6.7 & 1355.5 & -1.7 & 11.7 & 2.7 & 37.8 & 514 & 4.62 \\
\hline Bog pools & 110.0 & - & 930.0 & 1.4 & 13.1 & 3.8 & 49.5 & 39 & 6.08 \\
\hline Shrub-rich bog & 47.5 & B. 5 & 1626.8 & -1.5 & 4.7 & 0.1 & 26.2 & 329 & 4.03 \\
\hline Treed bog & 1.8 & 0.8 & 65.7 & -1.7 & 0.1 & -0.2 & 1.8 & 127 & 0.17 \\
\hline Conifer forest & 3.3 & 1.8 & 49.7 & -2.2 & 0.0 & -0.8 & 2.3 & 35 & 0.17 \\
\hline
\end{tabular}

All values with the exception of the annual methane emissions flux for the peatland type, $\mathrm{F}_{\mathrm{PT}}$, are in mg CH, $\mathrm{m}^{-2} \mathrm{~d}^{-1}$. The units of $\mathrm{F}_{\mathrm{PT}}$ are $\mathrm{g} \mathrm{m}^{-2} \mathrm{yr}^{-1}$. $\mathrm{Q} 1$ and $\mathrm{Q}^{3}$ refer to the upper and lower quartile.

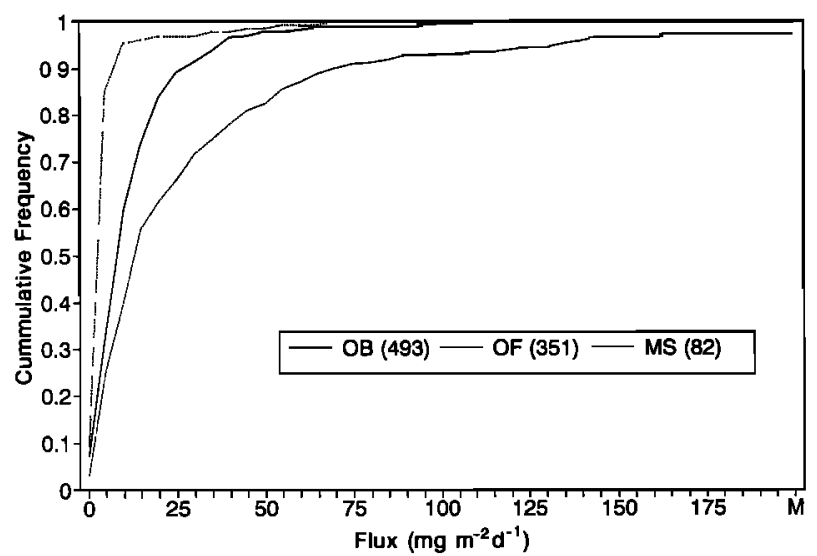

Fig. 3. The frequency distribution for methane fluxes for three different wetlands of the southern survey area (see caption of Figure 2 for wetland codes). saturated zone of the peatlands of the HBL [Mortsch, 1990], diffugion should be greatly reduced.

The largest methane fluxes, on a per unit area basis, were from the pools in the fens. They were 2 to 20 times larger than the fluxes from the adjacent peat surfaces (Table 5). In contrast the fluxes from the pools in the bogs were more comparable to the adjacent peatland. The pool fluxes were not measured directly like those for the peatlands but were calculated (see methods) which could lead to an overestimate of between 10 and 30\% [Kwan and Taylor, 1993]. Regardless of this possible error, the summary otatistics for $\mathrm{CH}_{4}$ flux from the pools in Table 5 clearly show the fluxes from the pools were larger than from the adjacent peat aurfaces in the fens. The pool fluxes also showed the same degree of variability and skewed distribution.

A summary of the methane fluxes measured from wetlands in the northern survey area is presented in Table 6 . The fluxes were much larger 
TABLE 6. Annual Mean Daily Methane Flux From Northern Survey Region.

\begin{tabular}{lccccccccc}
\hline Land Cover & Mean & $\begin{array}{c}\text { Standard } \\
\text { Error }\end{array}$ & Max. & Min. & Median & Q1 & $Q 3$ & N & FT \\
\hline $\begin{array}{c}\text { Coastal } \\
\text { marshes }\end{array}$ & 84.3 & 9.7 & 2255.0 & -2.6 & 43.3 & 17.5 & 68.3 & 270 & 8.0 \\
$\begin{array}{c}\text { Shallow } \\
\text { lakes }\end{array}$ & 125.5 & 15.8 & 1387.0 & 0.1 & 26.6 & 6.1 & 139.8 & 238 & 10. \\
$\begin{array}{c}\text { Open fen } \\
\text { Treed bog }\end{array}$ & 78.6 & 14.2 & 1585.0 & -0.6 & 24.0 & 1.9 & 73.7 & 293 & 6.6 \\
& 0.2 & 1.0 & 6.1 & -1.0 & 0.1 & -0.3 & 0.3 & 175 & 0.0 \\
\hline
\end{tabular}

All values with the exception of the annual methane emissions for the peatland type, $\mathrm{F}_{\mathrm{PT}}$, are in $\mathrm{mg}^{\mathrm{CH}} \mathrm{m}^{-2} \mathrm{~d}^{-1}$. The units of $\mathrm{F}_{\mathrm{PT}}$ are $\mathrm{g} \mathrm{m}^{-2} \mathrm{yr}^{-1}$.

from two wetlands types than from their southern survey counterpart: coastal marghes, mean flux was 2.7 times larger and the annual emissions were 3.5 times greater; and open fens without pools, mean flux and annual emissions were 10 times larger. The mean daily fluxes from the shallow lakes and treed bogs were comparable to the southern survey. It is not obvious why the fluxes should be larger in the northern portion of the HBL. The duration of warmer temperatures is shorter, but a larger proportion of the northern wetlands were wetter [Holland, 1992] than the southern wetlands [Moore et al.. this issue]. Possibly, the presence of permafrost inhibits drainage, maintaining higher water tables. Moore et al. [this issue] and Roulet et al. [1992b] demonstrate that the maintenance of aaturated conditions is more critical for higher fluxes than temperature, and only after wetland saturation is satisfied, do peat temperatures become a dominant environmental correlate. Moore et al. [this issue] demostrate that the potential rate of $\mathrm{CH}_{4}$ production was higher, while the potential rate of consumption was slightly lower, in laboratory incubations of peat from the northern gurvey area wetlands when compared to the rates obtained for peat from the southern survey area wetlands.

Extrapolation of the Methane Flux Along the NP-KL Transect and Northern Coast

The annual $\mathrm{CH}_{4}$ emissions observed for the wetlands along the NP-KL transect in the southern area of the HBL (Table 5) was combined with the areal coverage of wetlands and landscape types along the transect (Figures $2 a$ and $2 b$ ) to estimate the annual, habitat-weighted methane emission (Figure 2c). The annual emissions along the 140$\mathrm{km}$ transect were calculated using the areal extent of wetlands integrated over $5-\mathrm{km}$-wide linear strips, parallel to the James Bay coast. The increase in $\mathrm{CH}_{4}$ emissions is larger over the first $45 \mathrm{~km}$ than that of the last $75 \mathrm{~km}$. This increase corresponds to the replacement of treed fens, open fens, and conifer forests by open and treed bogs and wetlands with pools. The annual emissions from the pools themselves decreased from the coastal fens inland to the interior sites [Hamilton et al., this issue]. The mean annual habitat-weighted per unit area emission for the $\mathrm{NP}-\mathrm{KL}$ transect was $1.313 \pm 0.110 \mathrm{~g} \mathrm{CH}_{4} \mathrm{~m}^{-2} \mathrm{yr}^{-1}$. The standard error in flux along the transect, expressed as a percent of the estimated flux, ranged from 7.3 to 18.98 .

To assess the potential degree of bias introduced in the calculated flux by the large fens of the Moose River basin, the annual emission was recalculated by dividing the $40-\mathrm{km}-$ wide NP-KL transect into eight $5-\mathrm{km}$-wide subtransects. The change in $\mathrm{CH}_{4}$ emission from the coast inland to the interior follows the same trend for transects 3 to 8 (the most northwest transects), while the emisgion from transect 1 and 2 (the most southeast transects and in the Moose River basin) was considerably lower (Figure 4). The mean habitatweighted emission for transects 1 and 2 was 0.557 and $0.759 \mathrm{~g} \mathrm{CH}_{4} \mathrm{~m}^{-2} \mathrm{yr}^{-1}$, respectively, while the emission for other transects ranged from 1.133 to $1.785 \mathrm{~g} \mathrm{CH}_{4} \mathrm{~m}^{-2} \mathrm{yr}^{-1}$. Hence the variability in regional estimates of emissions can be $>40 z$ depending on the location of the survey area even in what appears to be very similar landscapes. The variability in estimates among transects 3 to 8 is < 308, i.e., the error calculated without the influence of the fens of the Moose River valley. This can be considered solely wetland survey variance because the same flux data were used on each transect and the only variables that changed were the fractional coverage of each wetland type.

\section{Methane Flux From the Hudson Bay Lowland}

With a wetland region as large as the HBL the use of Landsat-TM to determine the percent cover of wetland types becomes prohibitively expensive. Fortunately, Riley's [1982] ecological field surveys and analysis of air photography provides an estimate of the wetland coverage for the Ontario portion of the HBL, but there are no reliable data for the Quebec and Manitoba portions of the HBL. The Quebec portion of the HBL lies entirely within the same ecoclimatic region as that of the NP-KL transect, therefore data from the southern survey was assumed to be 


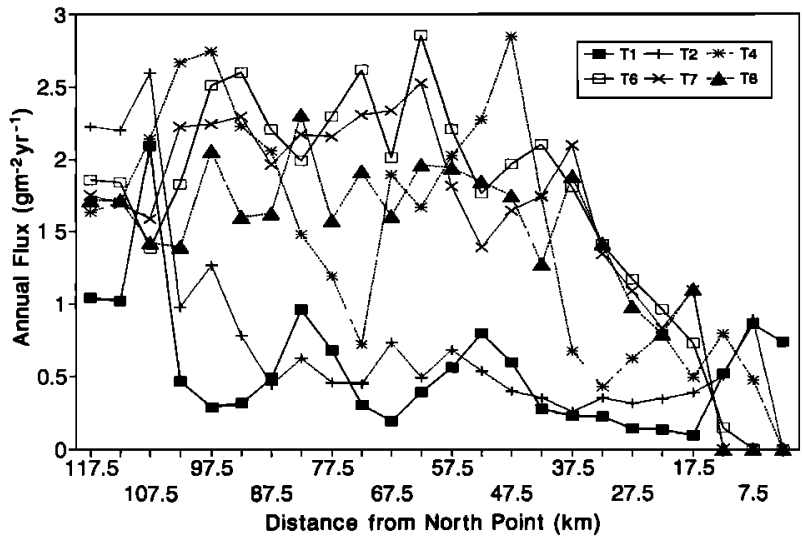

Fig. 4. Annual habitat-weighted methane emissions for six $5 \times 120 \mathrm{~km}$ subtransects of the NP-KL transect (two transects were emitted to enhance clarity) (see Figure 2 caption for wetland codes).

representative for that portion. The larger Manitoba portion of the HBL is in a very different climate region, as indicated by the presence of continuous permafrost. The distribution of wetlands in the low subarctic zone of Manitoba was assumed to be the same as the low subarctic zone in ontario. The high subarctic region of the HBL is climatically distinct from the low subarctic and boreal regions. Riley's data suggest that there is a smaller proportion of bogs than in the southern regions, and that open peatlands are more prevalent. Comparison of the Landsat cover analysis of the southern and northern survey areas confirms these differences. Open wetlands represent over 50\% of the northern survey area, open bogs are not present, and treed wetlands and foreats comprise 14 and 58 of the landscape, respectively. In contrast, open wetlands and treed wetland comprise 378 and 468 , respectively, the southern survey area. To incorporate these differences the annual emission of $\mathrm{CH}_{4}$ from the high subarctic region was computed using the fluxes obtained from the Churchill area (Table 6) and the different proportiong of wetlands determined from the $900 \mathrm{~km}^{2}$ Landsat-TM image of the Cape Churchill peningula (Table 4 ).

The results of the flux surveys show that the flux from pools in fens and bogs in both the southern (Table 5) and the northern regions (Table 6) were greater than the adjacent peatland. Because the ecological survey of Riley [1982] did not distinguish wetlands with pools from those without pools, we computed the ratio of the area of fens or bogs with pools to the total area of open fens or bogs from the NP-KL transect and applied that ratio to the entire HBL with the exception of the High Subarctic region. Based on Landsat data, $\approx 118$ of all open fens and bogs contained surface pools, and on the analysis of the color air photography the average surface inundation for an open fen and open bog was 31 and 418 respectively (see section on wetland coverage). For the high subarctic region the pools were treated explicitly as classified in the Landsat-TM image for the churchill area. This means that small pools (area $<900 \mathrm{~m}^{2}$ ) would be classified as a peatland rather than a pool and hence the flux would be underestimated.
The ecological survey of Riley [1982] has a broader level of aggregation of wetland classes and coarser resolution than the Landsat-TM surveys. To test the effect aggregation has on the annual habitat-weighted emission, the emission along the NP-KL transect was computed using the Landsat-TM derived data summarized into the Riley's six classes (Figure 2c). The mean emission using the full Landsat-TM classes was $1.313 \pm 0.110 \mathrm{~g} \mathrm{CH}_{4} \mathrm{~m}^{-2} \mathrm{yr}^{-1}$, while the aggregate wetland classes yielded a mean annual emission of $1.295 \pm 0.141 \mathrm{~g} \mathrm{CH}_{4} \mathrm{~m}^{-2} \mathrm{ys}^{-1}$, representing a 28 difference.

While the above analysis shows aggregation of wetland classes has little effect on the habitat-weighted emission, it does not test if the Riley [1982] estimates of the fractional coverage of each wetland type are good estimates and what size error in the emission might be introduced by using Riley's data. A direct comparison between Riley's coverage fractions and those derived by Landsat-TM can not be done because the southern survey area only makes up a small fraction of the total area surveyed by Riley. However, Riley divided his analysis into ecoclimatic regions, and the NP-KL transect straddles two of these regions: the low gubarctic and high boreal wetland regions. Using Riley's percent coverage for these two climate zones (Table 1 ), the mean habitat-weighted emisgion is 1.908 and $1.784 \mathrm{~g} \mathrm{CH}_{4} \mathrm{~m}^{-2} \mathrm{yr}^{-1}$, respectively. The mean emigsion for NP-KL subtransects 3 to 8 is $1.511 \mathrm{~g} \mathrm{CH}_{4} \mathrm{~m}^{-2} \mathrm{yr}^{-1}$. The emission, based on Riley's cover data, is between 18 to 268 higher. Sub-transects 3 to 8 were used to avoid the unique influence of the wetlands of the Moose River valley on the regional flux estimates (see Figure 4).

Based on the analyses described above, the total annual $\mathrm{CH}_{4}$ emission from the HBI in 1990 was $0.538 \pm 0.187^{4} \mathrm{Tg} \mathrm{CH} \mathrm{Cr}^{-1}$ (Table 7). If the southern transect data had gimply been extrapolated to the entire lowland, the total annual emission would have been $0.420 \mathrm{Tg} \mathrm{CH}_{4} \mathrm{yr}^{-1}$ (15\% lower). The single largest wetland contribution is from open bogs (Figure 5). This is due to the combination of higher emigsions and the large areally extent of open bogs. Treed bogs and uplands contributed similar amount of $\mathrm{CH}_{4}$. This is because the water table in the treed boge was very low $(<40 \mathrm{~cm})$, making the surface extremely dry, while in contrast the upland forests were relatively molst. The median flux from the forest was $0.0 \mathrm{mg} \mathrm{CH} \mathrm{m}^{-2} \mathrm{~d}^{-1}$, suggesting the forest was neither a significant source of $\mathrm{CH}_{4}$ nor a sink of $\mathrm{CH}_{4}$ as observed in other forests [e.g. Crill, 1991]. The low subarctic region is the most significant contributor of all the ecoclimatic regions because it occupies by far the greatest proportion of the HBL (Figure 5 ).

The above estimates are subject to considereable error. First are the errors associated with the flux estimates. These can be quantified in a manner similar to that used for the southern transect. Assuming no error in the areal estimate of the ecosystems, the standard error on the flux of $\mathrm{CH}_{4}$ from the HBL is $35 \%$. Extrapolating the fluxes by integrating the upper and lower quartile flux estimates from the northern and southern survey areas rather than the mean yields an upper estimate of $3.722 \mathrm{Tg} \mathrm{CH}_{4} \mathrm{yr}^{-1}$ and a lower estimate of $0.057 \mathrm{Tg} \mathrm{CH}_{4} \mathrm{yr}^{-1}$ (Figure 
TABLE 7: Annual Habitat-Weighted Methane Emissions ( $x 10^{-3} \mathrm{Tg} \mathrm{CH}_{4} \mathrm{y}^{-1}$ ) for the 1990 Snow-Free Period for the HBL organized by Wetland Type and Ecoclimate Region

\begin{tabular}{|c|c|c|c|c|c|}
\hline $\begin{array}{c}\text { Wetland/ } \\
\text { Region }\end{array}$ & MidBoreal & $\begin{array}{l}\text { High } \\
\text { Boreal }\end{array}$ & $\begin{array}{c}\text { Low } \\
\text { subarctic }\end{array}$ & $\begin{array}{c}\text { High } \\
\text { subarctic }\end{array}$ & $\begin{aligned} \text { Total by } \\
\text { Wetland Type }\end{aligned}$ \\
\hline Marshes & 7.1 & 3.8 & 12.1 & 0.1 & 23.1 \\
\hline $\begin{array}{l}\text { Open } \\
\text { fens }\end{array}$ & 6.5 & 10.3 & 92.3 & 30.9 & 140.0 \\
\hline $\begin{array}{r}\text { Treed } \\
\text { fens }\end{array}$ & 9.1 & 3.9 & 6.6 & 0.3 & 20.0 \\
\hline $\begin{array}{l}\text { Open } \\
\text { bogs }\end{array}$ & 57.2 & 52.9 & 209.4 & 12.0 & 331.5 \\
\hline $\begin{array}{r}\text { Treed } \\
\text { bogs }\end{array}$ & 3.2 & 1.6 & 7.8 & 0.7 & 13.3 \\
\hline Uplands & 3.2 & 0.8 & 5.6 & 0.6 & 10.2 \\
\hline $\begin{array}{c}\text { Total by } \\
\text { region }\end{array}$ & 86.3 & 73.3 & 333.8 & 44.6 & 538.0 \\
\hline
\end{tabular}

5). These estimates are a factor of 6.9 and 9.4 times, higher and lower than the $0.538 \mathrm{Tg} \mathrm{CH}_{4} \mathrm{yr}^{-1}$ estimated from the time-integrated average flux. A second source of error could come from the incorrect estimate of the coverage of the different types of wetlands. Unlike the error in the fluxeg which are statistical random errors, an error in the coverage of one wetland type necessitates an error in at least one additional class, i.e. the errors are not independent. The analysis of fluxes along transect 3 to 8 in the southern survey area suggested that variance in the area classified was $\approx 30 \%$. Assuming that the aggregation of wetland classes into six classes introduces a further 18 to $26 \%$ error, the total error for the extrapolated flux could be as large as $0.484 \mathrm{Tg} \mathrm{CH} \mathrm{yr}^{-1}$ or $\approx 908$. This would increase the overall error in the flux estimate to over 508. If it is assumed that the entire HBL is covered by the wetland type that yielded the highest amount of $\mathrm{CH}_{4}$ (open bogs) then the flux for the HBL would increase to $1.472 \pm 0.237 \mathrm{Tg} \mathrm{CH}$ $\mathrm{yr}^{-1}$, a factor of 2.7 times the mean estimate.

\section{Comparison of Extrapolationg With Airborne-Derived} Fluxes

A total of 18 regional $\mathrm{CH}_{4}$ flux estimates were done between July 11 and July 26 by the NASA Electra. The extrapolation model was also run for this same period for the southern and northern survey areas and the entire HBL, using enclosure and pond flux data obtained between July 11 and July 26. Five aircraft fluxes were obtained over the southern survey with a mean of $14 \pm 8 \mathrm{mg} \mathrm{CH}_{4} \mathrm{~m}^{-}$ $2 \mathrm{~d}^{-1}$, while the extrapolation model yielded $16 \pm$ $11 \mathrm{mg} \mathrm{CH}_{4} \mathrm{~m}^{-2} \mathrm{~d}^{-1}$, representing a factor of 1.1 difference (Table 8 ). The errors presented here are standard deviations, not standard errors, to facilitate the statistical comparison of the mean fluxes. There is no statistical difference in means based on a student $t$ test ( $p=0.05$ ) assuming unequal variance [Zar, 1984]. The comparison for the northern survey area is not as

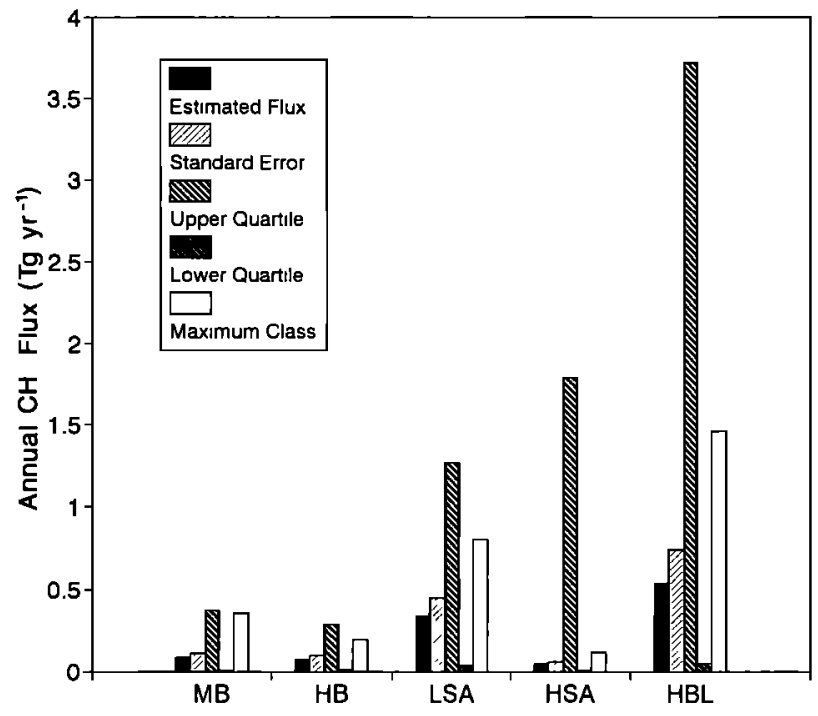

Fig. 5. The distribution of annual habitatweighted methane emissions (estimated flux) for the different ecoclimate regions of the HBL. Four different error scenarios are also shown. The standard error represents the estimated flux plus one standard error. The upper and lower quartile egtimates were derived by habitat-weighting the time-intergrated $Q 3$ and $Q 1$ fluxes for the northern and southern survey sites (see Tables 5 and 6 ). The maximum class was derived assuming that the entire HBL was covered with the highest emitting wetlands. MB, mid boreal; HB, high boreal; LSA, low subarctic; and HSA, high subarctic.

good: $12 \pm 16$ from the aircraft versus $44 \mathrm{mg} \mathrm{CH}_{4} \mathrm{~m}^{-}$ ${ }^{2} \mathrm{~d}^{-1}$ from the extrapolation model, a difference of 3.7. The southern flights were all centered over the Kinosheo Lake area which formed a large portion of the southern survey area, but the northern flights were never directly over the northern survey area at the churchill, Manitoba 
TABLE 8.: Comparison of Aircraft Derived Regional $\mathrm{CH}_{4}$ Fluxes ( $w^{\prime} \mathrm{CH}_{4}{ }^{\prime}$ ) and the Fluxes Determined Using the Extrapolation Model for the Period July $11-26,1990$

\begin{tabular}{|c|c|c|c|c|c|}
\hline $\begin{array}{l}\text { Flight } \\
\text { Leg }\end{array}$ & Date & Local Time & $\begin{array}{c}w^{\prime} \mathrm{CH}_{4}^{\prime} ; \\
m g m^{-2} d^{-1}\end{array}$ & $\begin{array}{c}\text { Mean of } \\
\text { Aircraft } \\
\text { Fluxes, } \\
\text { mg m } \mathrm{m}^{-2} \mathrm{~d}^{-1}\end{array}$ & $\begin{array}{l}\text { Flux From } \\
\text { Model } \\
\mathrm{mg} \mathrm{m}^{-2} \mathrm{~d}^{-1}\end{array}$ \\
\hline \multicolumn{6}{|c|}{ Southern Survey Area } \\
\hline \multirow[t]{2}{*}{7} & $7 / 17$ & 1110 & $26 \pm 6$ & & \\
\hline & $7 / 17$ & 1225 & $10 \pm 4$ & & \\
\hline \multirow[t]{2}{*}{16} & $7 / 22$ & 1417 & $19^{*}$ & $14 \pm 8$ & $16 \pm 11$ \\
\hline & $7 / 22$ & 1427 & $7^{*}$ & & \\
\hline 17 & $7 / 26$ & 1112 & $9 \pm 2$ & & \\
\hline \multicolumn{6}{|c|}{ Northern Survey Area } \\
\hline 13 & $7 / 21$ & 1317 & 31 & & \\
\hline 14 & $7 / 21$ & 1331 & 2 & $12 \pm 16$ & 44.1 \\
\hline 15 & $7 / 21$ & 1357 & 3 & & \\
\hline \multicolumn{6}{|c|}{ Other portions of the HBL } \\
\hline 2 & $7 / 11$ & 1548 & 7 & & \\
\hline 3 & $7 / 11$ & 1605 & $10 \pm 3$ & & \\
\hline 4 & $7 / 11$ & 1638 & 11 & & \\
\hline 5 & $7 / 11$ & 1653 & $6 \pm 3$ & & \\
\hline 6 & $7 / 11$ & 1720 & 15 & $9 \pm 6$ & \\
\hline 9 & $7 / 21$ & 1211 & -1 & & \\
\hline 11 & $7 / 21$ & 1226 & $13 \pm 3$ & & \\
\hline 12 & $7 / 21$ & 1258 & 20 & & \\
\hline \multirow[t]{2}{*}{19} & $7 / 26$ & 1822 & $12^{*}$ & & \\
\hline & $7 / 26$ & 1829 & $13^{*}$ & & \\
\hline $\begin{array}{l}\text { Mean for } \\
\text { HBL }\end{array}$ & & & $10 \pm 9$ & & $20 \pm 16$ \\
\hline
\end{tabular}

* Flight level values: these fluxes are based on only one flight level while all others are based on the flux divergence between two flight levels [Ritter et al., this issue].

area. The closest flight line (15) [Ritter, this issue, Figure 2] terminated $>60 \mathrm{~km}$ south of churchill. The standard deviation for the northern flights is much higher than that of the southern flights (coefficient of variation for the northern mean aircraft flux is 1338 compared to 578 for the southern survey area), but a direct statistical comparison for the northern survey area is not possible because the sample size is too small (e.g N-1 = 2 for the aircraft flux). one of the flights (13) near the northern survey area, did yield a flux of $31 \mathrm{mg} \mathrm{CH}_{4} \mathrm{~m}^{-2} \mathrm{~d}^{-1}$ which is closer to that of the extrapolated fluxes. The mean aircraft flux based on all 18 flux runs was $10 \pm 9$ compared to $20 \pm 16 \mathrm{mg} \mathrm{CH}_{4} \mathrm{~m}^{-2} \mathrm{~d}^{-1}$ from the extrapolation. These two mean fluxes are different by a factor of 2, but they are not statistically different based on a student $t$ test $(p=0.05)$ assuming unequal variance [ $\mathrm{zar}, 1984$ ] because there is a large variance associated with each mean. We consider this a confirmation of the extrapolation approach used in this study given the inherent spatial variability of trace gases fluxes.

\section{Discussion}

The methane flux from the HBL can be examined at three scales. At a small scale $(1$ $100 \mathrm{~m}^{2}$ ) the within-site and between-site variability can be related to ecological, chemical, edaphic, and physical differences among sites [Klinger et al., this issue; Moore et al., this issue]. At the mesoscale $\left(1-1000 \mathrm{~km}^{2}\right)$ the seasonal methane emissions can be examined in relation to the development of the landscape. In the case of the HBL, because of the sequential development of the landscape represented by the changing importance of various wetland types, the temporal changes in methane flux over several 
thousand yearg can be inferred. Finally, the significance of the whole HBL as a source of atmogpheric methane can be determined. The latter is important in the calculation of global methane budgets because of the areal extent of the lowland.

The change in methane flux along the southern transect displayed a pattern related to the development of the HBL. Previous studies have examined fluxes from different wetland types which were at different stages of succession [e.g. Crill et al., 1988; Moore et al., 1990; Roulet et al., 1992b] but there has been little attempt to place the measured fluxes in the context of the development of a peatland landscape. There is a very large body of literature on peatland formation and evolution (see Glaser [1987] for review). Klinger et al. (this issue) look at the change in methane flux along one successional sequence of the HBL. The HBL is a paludified landscape: the continuous peatland has formed by the coalescence of many individual peatlands that have evolved along eeveral different successional routes [Riley, 1982]. At the scale of the southern transect the various routes of succession result in a shift from the predominance of marshes and fens to more bogs and treed wetlands inland. This transect also represents a chronosequence of 4000 years. The combination of three different patterns result in the overall pattern of increasing emissions from the coast inland: (1) the peat surfaces of the fens emit far less methane than the surfaces of the interior bogs; (2) the pools on the fens emit much more methane than the adjacent peat surfaces, and; (3) the fraction of open peatlands with a significant amount of ourface water increases from the fen near the coast to the interior bogs.

It has been shown that fens generally emit more methane than bogs and this has been attributed to the higher net primary productivity (NPP) of fens [e.g., Aselmann and Crutzen, 1989] and greater gurface wetness in fens [Glaser, 1987]. The pattern observed in this study is exactly opposite: the fens yield the least methane and the interior bogs the most. This results from differences in the production and oxidation of $\mathrm{CH}_{4}$ among the various wetlands. The fen peat displayed the greatest potential for the production of $\mathrm{CH}_{4}$ of any peat type along the transect [Moore et al., this issue] but the same peat also had a dieproportionately higher potential for the oxidation of $\mathrm{CH}_{4}$. The general pattern of $\mathrm{CH}_{4}$ fluxes was confounded by the presence of pools on many of the peatlands. The flux of $\mathrm{CH}_{4}$ from the pools is a function of the biogeochemical processes which occur in the pools themselves [Hamilton et al., this issue] and possible decomposition of peat from the sediments and sides of the pool [Moore et al., this issue]. The relative importance of the flux of $\mathrm{CH}_{4}$ from the pools in the regional flux is not because the pools themselves are unusually large emitters, as the flux from pools is comparable to the flux from many peatlands [cf. Crill et al., 1988; Moore et al., 1990; Sebacher et al., 1986; Whalen and Reeburgh, 1988], but because the vegetated portions of the HBL peatlands are very low emitters compared to many other peatlands not in the HBL.
When the NOWES was originally conceived [1988], it was assumed that the HBL would emit $\approx$ 7 to $8 \mathrm{Tg} \mathrm{CH} \mathrm{yr}^{-1}$, based on 108 of the flux for northern wetlands derived by Matthews and Fung [1987], as the HBL comprises $\approx 10 \%$ of all northern wetlands. Our estimate of $0.538 \pm 0.187 \mathrm{Tg} \mathrm{CH}_{4} \mathrm{Yr}^{-}$ 1 is about 15 times smaller. More recently, Aselmann and Crutzen [1989] and Fung et al. [1991] have reduced the northern wetland source to 22 and $35 \mathrm{Tg} \mathrm{CH} 4 \mathrm{Yr}^{-1}$, repectively. Ten percent of these estimates is 2.2 and $3.5 \mathrm{Tg} \mathrm{CH}_{4} \mathrm{yr}^{-1}$, which is still 4 to 6 times larger than our estimate. Using the highest flux estimate from the HBL based on the error analysis using the upper quartile (3.722 $\mathrm{Tg} \mathrm{CH}_{4} \mathrm{yr}^{-1}$ ), there is little difference between our estimate and the prorated estimates using Aselmann and Crutzen [1989] and Fung et al. [1991], but using the linear combination of errors $\left(0.484 \mathrm{Tg} \mathrm{CH}_{4} \mathrm{yr}^{-1}\right.$ ) there is still a factor of 2 to 3 difference. However, when the potential sources of errors in the global budgets are also considered the differences reported above are small. If the Western Siberian lowland (WSI) has eimilar fluxes to the HBL, then the overall emissions from northern wetlands may be as low as $17 \mathrm{Tg} \mathrm{CH} \mathrm{yr}^{-1}$. This is based on $2.4 \times 10^{6} \mathrm{~km}^{2}$ of northern wetlands, using the Aselmann and Crutzen flux from northern wetlands not in the HBL and WSI, and assuming the HBL and WSL represent $30 \%$ of this area and that the HBL and WSL are ecologically similar. The latter assumption is not unreasonable since they both developed on glacial emergent coastlines, and they experience gimilar climates [Botch and Masing, 1983; Mortsch, 1990; Riley, 1982]. This would mean northern wetlands represent only 3 to 48 of the global $\mathrm{CH}_{4}$ source. This study lends strong empirical evidence for the model estimates of Fung et al. (1991).

The lower estimate results from the very low fluxes measured during the NOWES experiment and not from differences in the areal extent of wetlands assumed in our extrapolation. It is possible that the very low fluxes could be a result from the enclosures yielding systematically low fluxes. However, the comparison of the flux data from the aircraft and fluxes extrapolated using remote sensing from enclosure and pond measurements compared to within a factor of 3.7 in the worst case of the northern survey area, and to within a factor of 2 over the entire HBL. During the NOWEs there were also several periods where the $\mathrm{CH}_{4}$ fluxes were measured simultaneously by enclosures, and tower and airborne eddy correlation systems over the Kinosheo Lake area (Edwards et al., thil issue; Ritter et al., this issue). While a detailed three-way comparison has not yet been made because analysis of the "footprints" still has to be undertaken, preliminary results indicate that they all agree to within a factor of 2 . Even if the enclosures underestimated the flux by the worst case factor of 3.7, the annual emisgion from the HBL would increase to only $1.3 \mathrm{Tg} \mathrm{CH} 4 \mathrm{yr}^{-1}$. This would have no effect on the conclusions. Likewise, the study period was wetter $(\approx 208)$ and warmer $\left(\approx 2^{\circ} \mathrm{C}\right)$ than normal which would lead to higher not lower than normal fluxes. Whalen and Reeburgh [1992], in a 4-year times series, demonstrate a large within site and interannual variability in methane flux. 
Their work [e.g. Bartlett et al., 1989; Moore et al., 1990] shows that the separation of the temporal from the spatial variance will require long-term measurements spanning 5 to 10 years using many enclosures at one location.

Acknowledgments. We would like to thank John Riley for his assigtance in identifying the ecological characteristics of the sites in the southern survey area and the two reviewers of this manuscript for their helpful advice. This is scientific contribution 92-2 of the Canadian Institute for Research in Atmospheric Chemistry (CIRAC). The work described herein was undertaken as part of the CIRAC/NASA Northern Wetlands study which was funded in part by a collaborative grant from NSERC Canada, Atmospheric Environment Service, Environment Canada, and NASA Global Troposphere Experiment.

\section{References}

Aselmann, I., and P.J. Crutzen, Global distribution of natural freshwater wetlands and rice paddies, their net primary productivity, seasonality and possible methane emissions, J. Atmos. Chem., 8, 307$358,1989$.

Barford, N.C., Experimental Measurements: Precision, Error and Truth, 2nd Ed. John Wiley, New York, 159 pp. 1985.

Bartlett, D.S., K.B. Bartlett, J.M. Hartman, R.C. Harriss, D.I. Sebacher, R. Pelletier-Travis, D.D. Dow, and D.P. Brannon, Methane emissions from the Florida Everglades: Patterns of variability in a regional wetland ecosystem, Global Biogeochemical Cycles, 3, 363-374, 1989.

Botch, M.S., and V.V. Masing, Mire ecosystems of the U.S.S.R., in Ecosystems of the World 48 - Mires: Swamp, Bog, Fen, and Moor, edited by A.P.P. Gore, pp. 95-152, Elsevier, New York, 1983.

Cowell, D.W., Earth sciences of the Hudson Bay lowland: Literature review and annotated bibliography, Work. Pap. 18, Lands Dir., Environ. Can. Ottawa, 1982

Crill, P.M., seasonal patterns of methane uptake and carbon dioxide release by a temperate woodland soil, Global Biogeochem. Cycles, $\underline{5}$, 319-334, 1991 .

Crill, P.M., K.B. Bartlett, R.C. Harriss, E. Gorham, E.S. Verry, D.I. Sebacher, L. Madzar, and $W$. Sanner, Methane flux from Minnesota peatlands, Global Biogeochem. Cycles, 2, 371-384, 1988.

Crutzen, P.J., Methane sources and sinks, Nature, 350, 380-381, 1991.

Dise, N. B., Winter fluxes of methane from Minnesota peatlands, Biogeochemistry, 17 , 71-83, 1992 .

Edwards, G. C., H. H. Neumann, G. den Hartog, G. W. Thurtell, and G. Kidd, Eddy correlation measurements of methane fluxeg using a tuneable diode laser at the Kinosheo Lake tower site during the Northern wetlands study (NOWES), J. Geophys. Res., this issue.

Fung, I., J. John, J. Lerner, E. Matthews, M. Prather, L.P. Steele, and P.J. Fraser,
Three-dimensional model gynthesis of the global methane cycle, J. Geophys. Res., 96 (D7), 13,033-13,065, 1991 .

Glaser, P. H., The ecology of patterned boreal peatlands of northern Minnesota: A community profile, US Fish Wildl. Serv. Reg. Rep. 85(7.14), 98 Pp. 1987.

Glooschenko, W. A., N. T. Roulet, L. A. Barrie, H. I. Schiff, and H. G. McAdie, The Northern Wetland Study (NOWES): An Overview, $\mathrm{J}$. Geophys. Res., this issue.

Hamilton, J. D., C. A. Kelly, J. W. Rudd, R.H. Husselein, and N.T. Roulet, Flux to the atmosphere of $\mathrm{CH}_{4}$ and $\mathrm{CO}_{2}$ from wetland ponds on the Hudson Bay Lowland, (HBL) J. Geophys. Res., this issue.

Holland S., Methane emission in a subarctic wetland environment, M.Sc. Thesis Department of Geography, McMaster University, Hamilton, Ontario, $108 \mathrm{pp}, 1992$.

Intergovernmental Panel on climate Change, climate Change: The IPCC scientific Assessment, edited by J.T. Houghton, G.J. Jenkins, and J.J. Ephraums, 365 pp. Cambridge University Press, New York, 1990.

Klinger, L. E. F., P. R. Zimmerman, J. P. Greenberg, L.E. Heidt, and A. B. Guenther, Carbon trace gas fluxes along a successional gradient in the Hudson Bay lowland, $\mathrm{J}$. Geophys. Res., this issue.

Kwan, J., and P. A. Taylor, On gas flux from small lakes and ponds, Boundary Layer Meteorol., in press, 1993.

Martini, I.P., The Hudson Bay lowland: Major geologic features and assets, Geol. Mijnbouwk, 68, 25-34, 1989.

Matthews, E., and I. Fung, Methane emissions from natural wetlands: Global distribution, area, and environmental characteristics of sources, Global Bioqeochem. Crcles, 1, 61$86,1987$.

Moore, T.R., N.T. Roulet, and R. Knowles, spatial and temporal variations of methane flux from subarctic/northern boreal fens, Global Biogeochem. Cycles, 4, 29-46, 1990.

Moore, T.R., A. Heyes, and N.T. Roulet, Methane emissions from wetlands of southern Hudson Bay lowland, J. Geophys. Res., this issue.

Mortsch, L. (ed), Eastern Canadian boreal and sub-arctic wetlands: A resource document, climatol. Stud. 42, 169 pp. Min. of Environ, Ottawa, 1990.

Mortsch, L., An assessment of the climate of 1990 during the CIRAC/ABLE-3B Northern Wetlands study, EOS Trans. AGU, 71 (17), 84, 1991.

National Wetlands Working Group (NWWG), in Wetlands of Canada, Ecol. Iand class. Ser. 24, Sustainable Dev. Branch, Environment Can., Ottawa, and Polysci., Montreal, 452 pp. 1988 .

Pala, S., and A. Boissonneau, Wetland classification maps for the Hudson Bay Lowland, Nat. Can., 109, 653-659, 1982.

Reeburgh, W. S., and S. C. Whalen, High latitude ecosystems as $\mathrm{CH}_{4}$ sources, Ecol. Bull (Stockholm), 42, 62-70, 1992.

Riley, J.L., Hudson Bay Lowland floristic inventory, wetland catalogue, and conservation strategy, Nat. Can., 109, 543555,1982 . 
Riley, J.L., Southern Ontario bogs and fens of the Canadian Shield, in Wetlands: Inertia or Momentum, edited by M.J. Bardecki and $N$. Patterson, 355-367, Federation of Ontario Naturalista, Toronto, 1988.

Ritter, J. A., J. D. W. Barrick, G. W. Sachse, G. I. Gregory, M. A. Woemer, C.E. Watson, G. F. Hill, and J. E. Colling, Airborne flux measurements of trace species in an arctic boundaxy layer, J. Geophys. Res., 97, $16,601-16,625,1993$.

Ritter, J. A., J. D. W. Barrick, C. E. Watson, G. W. Sachse, G. L. Gregory, B. E. Anderson, M.A. Woerner, and J. E. Colling, Airborne boundary layer flux measuremente of trace gas species over Canadian boreal forest and northern wetland regions, J. Geophyg. Res., this issue.

Roulet, N. T., L. Barrie, W. A. Gloogchenko, R. C. Harriss, J. I. MacPherson, T. R. Moore, H. H. Neumann, R. Protz, and H. I. Schiff, Northern Wetlands Study (NOWES): an assessment of the role of northern Canadian wetlands in the exchange of atmospheric trace gases, Ecol. Bull. (Copenhagen), 42 , 77-85, 1992a.

Roulet, N. T., R. Ash, and T. R. Moore, Methane flux from low Boreal forest wetlands, $\mathrm{J}$. Geophys. Res., 97, 3739-3749, $1992 \mathrm{~b}$.

Ruffner, J.A., and F.E. Bair (eds.), weather of U.S. Cities, vol. 1, City Reports: Alabama Missouri, Gale research Company, Detroit, Mich., 1985.

Sachse, G. W., J. E. Colling Jr., G. F. Hill, L o. Wade, I. G. Burney, and J. A. Ritter Airborne tuneable diode laser sensor for high-precision concentration and flux measurements of carbon monoxide and methane, Proc. SPIE Int. Symp. on Laser Spec., 1433 145-156, 1991 .

Sebacher, D.I., R.C. Harrisg, K.B. Bartlett, S.M. Sebacher, and S.S. Grice, Atmospheric methane sources: Alaskan tundra bogs, and alpine fen, and a subarctic boreal marsh, Tellus, 38(B), 1-10, 1986.

Wanninkhof, R., J. Ledwell, and J. Crusius, Gas transfer velocities on lakes measured with sulfur hexafluoride, in Air Water Mass Transfer, eidted by S. C. Wilhelms and J. S. Gulliver, 69-84, Am. Soc. Civil Eng., New York, 1990 .

Whalen, S.C., and W.S. Reeburgh, Methane flux time series for tundra environments, Global Biogeochem. Cycles, 2, 399-409, 1988.

Whalen, S. C., and W. S. Reeburgh, Interannual variations in tundra methane emissions: A four-year time series at fixed sites, Global Biogeochem. Cycleg, 6, 139, 1992.

Zar, J.H., Biostatistical Analysis, 2nd Ed., Prentice-Hal1, Englewood Cliffe, N.J. 1984

A. Jano, Ontario Centre For Remote Sensing, Ministry of Natural Resources, 90 Sheppard Avenue E., North York, ON M2N $3 A 1$.

C. A. Kelly, Department of Microbiology, University of Manitoba, Winnipeg, MN R3J $2 \mathrm{~N} 2$

L. F. Klinger, National Center for Atmospheric Research, P. O. Box 3000, Boulder, co 80307-3000.

T. R. Moore and N. T. Roulet, Department of Geography, MCGill University, 805 Sherbrooke street W., Montreal, QC H3A $2 \mathrm{~K} 6$.

R. Protz, Land Resource science, Guelph University, Guelph, ON NIG 2 W 1 .

J. A. Ritter, Atmospheric Science Division, NASA Langley Research Center, Hampton, VA 236655225 .

W. R. Rouse, Department of Geography, McMaster University, Hamilton, ON L8S 1R4.

(Received May 28, 1992; revised December 23 1992; accepted January 25, 1993.) 